\title{
FICCIONES INMUNITARIAS. SOBRE LA LÓGICA DE LA INMUNIDAD EN LA CULTURA CONTEMPORÁNEA
}

\section{Immunitarian fictions. On the logic of immunity in contemporary culture}

\author{
Jaume Peris Blanes* \\ * Universitat de València \\ jaume.peris@uv.es
}

\begin{abstract}
Palabras clave
Inmunidad

Contagio

Epidemia

Zombi

Shock

Resumen

Este trabajo desarrolla el concepto de "ficción inmunitaria" tomando como ejemplos paradigmáticos relatos de epidemias y narrativas zombi, que comparten la idea del contagio como matriz principal de la narración. El artículo trata de abordar la siguiente pregunta: ¿de qué modo estas ficciones, y otras similares, participan del imaginario de la inmunidad y escenifican, a la vez, algunas de sus contradicciones internas? Para ello reflexiona en torno a un conjunto de productos culturales de difusión masiva (novelas, series televisivas, obras cinematográficas). En primer lugar, analiza cómo estas ficciones ponen en relato los miedos y angustias sociales vinculadas a las tensiones del "paradigma inmunitario" y representan las relaciones complejas entre la comunidad, su amenaza y las formas posibles de inmunización. En segundo lugar, describe cómo generan una experiencia narrativa de impacto que busca producir un miedo derivativo en su público que, sin duda, refuerza y consolida la lógica social de la inmunidad y legitima sus múltiples formas de violencia ante la amenaza.
\end{abstract}

\section{Abstract}

This article develops the concept of "immunitarian fiction" taking as paradigmatic examples epidemics and zombie narratives, which share the idea of contagion as the main matrix of their narrative. The article tries to address the following question: in what way do these fictions, and other similar ones, participate in the imaginary of immunity and, at the same time, show some of their internal contradictions? For this, the text reflects on a set of cultural products of mass diffusion (novels, television series, cinematographic works). We analyze, in the first place, how these fictions highlight the fears and social anxieties linked to the tensions of the "immune paradigm" and represent the complex relationships between the community, its threats and the possible forms of immunization. In a second moment, the text describes how they generate an impacting narrative experience that seeks to produce a derivative fear in its audience that reinforces and consolidates the social logic of immunity and legitimizes its multiple forms of violence facing threats.

Peris Blanes, J. (2018). Ficciones inmunitarias. Sobre la lógica de la inmunidad en la cultura contemporánea. Papeles del CEIC. International Journal on Collective Identity Research, vol. 2018/1, papel 183, CEIC (Centro de Estudios sobre la Identidad Colectiva), UPV/EHU Press, http://dx.doi.org/10.1387/pceic.17680

Recibido: 03/2017; Aceptado: 10/2017 


\section{INTRODUCCIÓN ${ }^{1}$}

Cuando en 1947 Albert Camus publicó por primera vez La peste (1983) incluyó, a modo de apertura, una cita de Daniel Defoe en la que aludía al carácter metafórico o incluso alegórico del tratamiento narrativo de la epidemia: "tan razonable como representar una prisión de cierto género por otra diferente es representar algo que existe realmente por algo que no existe". Efectivamente, la novela narraba los efectos de una epidemia de peste en la ciudad argelina de Orán, pero al hacerlo aludía también, de un modo desplazado, a la Francia ocupada por el nazismo y a los procesos de fascistización y de resistencia que tuvieron lugar en ella. Esa asociación entre enfermedad y política le valió a Camus una intensa polémica, en tanto que parecía identificar la ocupación militar y política con una fuerza de la naturaleza y, en cierto sentido, corría el riesgo de despolitizar y deshistorizar la extensión violenta del fascismo (Judt, 2009). Sin embargo, una lectura atenta de La peste revela un nexo que la cercanía del trauma de la ocupación no permitía ver y que amplía la potencia alegórica de la peste: lo más importante de la novela no es la asociación más o menos evidente entre la ocupación nazi y el carácter destructivo de una epidemia mortal, sino el modo en que en la lucha contra la enfermedad se despliegan mecanismos que, en la mente del lector de la época, no podían sino recordar a las prácticas del nazismo. Segregación de la población, prohibición, aislamiento, control de la información, cremaciones masivas, conversión de tranvías públicos en transporte para cadáveres y de un estadio de futbol en enfermería y campo de concentración... todos esos procesos, utilizados para detener la plaga, conectaban imaginariamente con acciones similares llevadas a cabo por el gobierno de Vichy y, en general, por los fascismos europeos. Dicho de otro modo, a pesar de los buenos propósitos y las dudas existenciales de los protagonistas, la razón científica y médica actuaba en la novela como una fuerza de ocupación, decretando un estado de

\footnotetext{
${ }^{1}$ Este trabajo se nutre de conversaciones y discusiones mantenidas en dos ámbitos diferentes. Por una parte, con Miguel Ángel Martínez, en torno a su trabajo sobre las representaciones culturales de la enfermedad (2015) y el concepto de "imaginación política de la inmunidad" (en prensa), que inspira en buena medida este ensayo. Por otra parte, con Gabriel Gatti y el grupo de investigación que dirige sobre Desapariciones. Muy especialmente quiero valorar las aportaciones bibliográficas de los grupos de trabajo formados por el propio Gatti, Iñaki Robles Elong, Silvia Rodríguez Maeso, Ramón Sáez, Ignacio Irazuzta y Pamela Colombo.
} 
excepción permanente y aplicando políticas de choque sobre el cuerpo social para evitar la propagación de la enfermedad.

En ese sentido, La peste ponía en relato la continuidad entre la violencia masiva de los fascismos y las prácticas sociosanitarias utilizadas para erradicar una enfermedad, poniendo el énfasis en aquello que las hermanaba: la perspectiva inmunitaria en la que se legitiman sus modos de control social. De hecho, las medidas tomadas para erradicar la peste suponían una violencia sobre el cuerpo social que se legitimaba en su promesa de prevenir una amenaza mayor, igual que la violencia de la ocupación nazi se legitimaba en la necesidad de conjurar la amenaza del enemigo interior ${ }^{2}$. En ambos casos el estado de excepción hallaba su razón de ser en la voluntad de combatir aquello que amenazaba (de forma real o ilusoria) a la propia supervivencia de la comunidad.

Esa continuidad parece poder explicarse a partir de lo que Esposito ha denominado el "paradigma inmunitario" (2005), aquel que permite analizar de forma vinculada procesos y lógicas de la modernidad que habitualmente se han leído desde paradigmas diferentes. Para Esposito, la gran variedad de procesos jurídicos, políticas sanitarias y construcción de identidades o conflictos políticos, podrían leerse desde el mismo paradigma biopolítico, basado en la necesidad de salvaguardar la integridad de la comunidad y de frenar la intrusión de elementos ajenos que pueden llegar a ser destructivos para ella.
"Ya sea el asediado el cuerpo de un individuo, por una enfermedad propagada; el cuerpo político, por una intromisión violenta; o el cuerpo electrónico, por parte de un mensaje aberrante, lo que permanece invariado es el lugar en el cual se sitúa la amenaza, que es siempre el de la frontera entre el interior y el exterior, lo propio y lo extraño, lo individual y lo común. Alguien o algo penetra en un cuerpo - individual o colectivo-y lo altera, lo transforma, lo corrompe. El término que mejor se presta a representar esta mecánica disolutiva - justamente por su polivalencia semántica, que lo ubica en el cruce entre los lenguajes de la biología, el derecho, la política y la comunicación- es 'contagio'. Lo que antes era

\footnotetext{
${ }^{2}$ Comentario aparte exigiría el hecho de que en la novela de Camus la ciudadanía de Orán se identificaba prácticamente con la ciudadanía francesa, en una suerte de naturalización de la lógica colonial que pasaba por alto las medidas de segregación racial y la estratificación económica y social de la Argelia colonial. En ese sentido, resulta irónico que, al alegorizar la ocupación francesa por los nazis, Camus invisibilizara otra forma de ocupación política y militar, como fue la colonización francesa.
} 
sano, seguro, idéntico a sí mismo, ahora está expuesto a una contaminación que lo pone en riesgo de ser devastado" (ibidem: 10).

En un fino análisis conceptual, Esposito construye su idea de inmunidad en relación directa con la de comunidad. Ambos conceptos son variaciones morfológicas de la misma raíz lingüística: el munus. Si la communitas implica la posibilidad de abrir la identidad individual al contacto con los demás, la immunitas es la energía defensiva y ofensiva desplegada para que esa apertura no derive en catástrofe. Dicho de otro modo, la inmunidad hace referencia a los dispositivos que la comunidad despliega para conjurar cualquier elemento que venga a amenazarla. La inmunidad, por tanto, está ligada a procesos de violencia hacia lo ajeno y a una continua redefinición de la frontera entre lo que forma parte de la comunidad y lo que, viniendo de afuera, amenaza con destruirla. Por ello, "cuando la inmunidad, aunque sea necesaria para nuestra vida, es llevada más allá de un cierto umbral, acaba por negarla, encerrándola en una suerte de jaula en la que no sólo se pierde nuestra libertad, sino también el sentido mismo de nuestra existencia individual y colectiva" (Esposito, 2012: 17).

Esa es la contradicción fundamental que resaltan las investigaciones de Esposito: "aquello que salvaguarda el cuerpo -individual, social, político- es también aquello que impide su desarrollo. Y aquello que también, sobrepasado cierto punto, amenaza con destruirlo" (ibídem: 18). Dicho de otra forma, la violencia destinada a salvaguardar los límites de la comunidad, impidiendor que agentes externos y potencialmente amenazantes entren en ella, pueden derivar en el constreñimiento de las propias formas de vida de la comunidad, incluyendo procesos internos de militarización, vigilancia y disciplina. De ese modo, la violencia que debía protegerla amenaza con destruir la propia comunidad.

Esa modalidad de la violencia inmunitaria es la que Camus puso de relieve con su relato y la que le permitía trazar esa siniestra continuidad entre los procedimientos de segregación, aislamiento y tratamiento de la población en el contexto de la ocupación nazi y en las políticas sociosanitarias puestas en marcha en la novela para combatir la extensión de la epidemia. En ese sentido, la novela de Camus es una ficción cuyo motor narrativo es la propia lógica de la inmunidad y que ofrece una solución narrativa eficaz a las tensiones de su época. 
Ello la conecta con una serie de relatos, más cercanos en el tiempo, que han utilizado la figura del contagio o la presencia de una alteridad amenazante para hilar sus tramas y argumentos e incluso, no pocas veces, para legitimar la violencia destinada a erradicarla. Esos relatos son los que proponemos denominar "ficciones inmunitarias" (Peris Blanes, en prensa) que constituirian uno de los canales simbólicos en los que se expresa y se construye lo que Martínez ha denominado la "imaginación política de la inmunidad" (en prensa) y que incluiría lo que en este trabajo llamaremos un "reparto inmunitario de lo sensible". Sin duda, las películas, series televisivas y novelas en torno a la expansión incontrolada de virus extremos podrían ser consideradas como paradigmas de esta narratividad que replica, en el mundo de la ficción, algunos de los miedos sociales en torno a la vulnerabilidad física en un mundo cada vez más conectado $y$, por tanto, propicio a un contagio global. Pero una figuración y un modo narrativo similar emerge en ficciones que, en principio, nada tienen que ver con virus, bacterias ni invasiones celulares: en múltiples relatos contemporáneos, la presencia del otro (social, étnico, geográfico, sexual, etc.) aparece vinculada a un contagio potencial $y$, por tanto, a la necesidad de inmunizar a la comunidad frente a la amenaza de su disolución.

En este trabajo nos centramos en las ficciones que parten explícitamente de la idea de contagio desde las narraciones epidémicas a los relatos zombi. Pero buena parte de las ficciones culturales masivas que, de un modo u otro, argumentan o legitiman políticas de inmunidad y las violencias que las acompañan comparten, a pesar de sus diferencias, algunos de los rasgos mayores que describimos a continuación. Todas estas ficciones, de hecho, ponen en relato los miedos y angustias sociales vinculadas a las tensiones del "paradigma inmunitario" que refuerzan los imaginarios de la amenaza exterior pero, a la vez, intervienen sobre ellos modificándolos y dándoles una dirección emocional determinada. Todas ellas, pues, pueden leerse como una puesta en relato de las relaciones conflictivas entre las identidades comunitarias y aquello que las amenaza desde el exterior.

Las ficciones que nos ocupan dan soluciones muy diferentes al problema de la inmunidad. Algunas de ellas argumentan, sin duda, la necesidad de reforzar los dispositivos inmunitarios, legitimándolos emocionalmente y argumentando su inevitabilidad. Otras, por el contrario, focalizan su atención en el carácter destructor de la violencia 
inmunitaria, y en sus efectos desestructuradores sobre la comunidad. Las más se limitan a enunciar las contradicciones entre la necesidad de la inmunización y sus riesgos potenciales. En cualquier caso, la relación entre inmunización y violencia aparece en ellas como una tensión que parece traducir un malestar social generalizado.

\section{IMAGINACIÓN DEL DESASTRE Y ESTADO DE EXCEPCIÓN NARRATIVA}

En La peste, la epidemia se desarrollaba y extendía a una escala local: la ciudad de Orán era aislada del resto de mundo para evitar la proliferación $y$, de ese modo, la ciudad argelina se convertía en un espacio cerrado que debía autorregular los estragos de la enfermedad. En la película Contagio (Soderbergh, 2011), se nos presenta una versión de la epidemia mucho más acorde a las ansiedades contemporáneas en torno a la infección: la interconectividad del mundo global es la plataforma perfecta para una extensión incontrolada y global del virus letal, que se extiende en apenas unos días desde Hong Kong al resto del mundo: "el turismo y la movilidad moderna (...), se configuran como instrumentos perfectos para diseminar el virus por todo el mundo" (Korstanje, 2012: 265). La potencia del filme radica precisamente en replicar en la propia estructura narrativa la interconectividad del mundo global que hace posible el contagio múltiple: la extensión de la enfermedad se nos presenta a través de diferentes historias conectadas por el virus.

En Contagio el origen de la epidemia se halla en Hong Kong, directamente relacionado con una imagen estereotipada de China como espacio de alteridad, en el que el hiperdesarrollo se cruza con la ausencia de controles de calidad en lo alimentario. El carácter aparentemente exógeno del virus contrasta con el modo inmediato en que la élite mercantil internacional lo contrae. En una película como Estallido (Petersen, 1995), que fijó las claves de la narrativa epidémica en los noventa, el virus letal provenía del Congo -entonces denominado Zaire, construido visualmente como un espacio de alteridad radical-, y solo entraba en Estados Unidos por la irresponsabilidad de un joven trabajador del centro de control de animales, de marcada estética grunge, que trataba de hacer negocio ilegal con un mono infectado: si bien el virus provenía del espacio abyecto y animalizado de África, su penetración en Estados Unidos solo tenía lugar a partir de un acto fuera 
de la ley, producido por un sujeto indisciplinado $y$, en ese sentido, representado como portador de riesgo (Ferrer Ventosa, 2015: 195).

Sin embargo, en la película de Soderbergh es la propia ley del mercado y las exigencias de circulación del capital las que aseguran la extensión incontrolada del virus. De esa forma, Contagio pone en relato la contracara del capitalismo contemporáneo: frente a los discursos celebratorios que ponen el acento en las posibilidades de movilidad global y la expansión del capital, la presencia del virus alerta de los riesgos de esa interconectividad.

Esa relación entre desarrollo capitalista y expansión de la enfermedad puede verse ya en un clásico de la literatura epidémica tan temprano como Diario del año de la peste (2012/1722), donde Daniel Defoe ya establecía una relación entre las formas de circulación del capital y los canales de diseminación de una plaga que se extendía fundamentalmente en la plaza del mercado y en las rutas comerciales. En realidad, como señalan Boluk y Lenz (2010), desde el comienzo de la modernidad los relatos sobre la infección biológica han servido para expresar otras angustias de más difícil representación, relacionadas con los cambios de la modernidad en general y con las transformaciones del capitalismo en particular. Esto es, las narrativas del contagio epidémico hablan sin duda de los estragos de la enfermedad, y argumentan la necesidad imperiosa de desarrollar mecanismos sociales para combatir la amenaza, reforzando y legitimando los dispositivos de control y disciplinamiento de la población que acompañan a los protocolos de prevención del contagio. Pero al hacerlo ponen también en escena otros miedos que no tienen que ver directamente con la enfermedad sino con otras amenazas más difusas, que carecen de narrativas claras para ser expresadas (Sundaram, 2012). Dicho de otro modo, los relatos del contagio biológico abastecen a las sociedades modernas $-y$ muy intensamente a la cultura actual- de marcos narrativos solventes para dar cuenta de miedos y angustias difíciles de definir, que carecen de marcos narrativos y cuadros de sentido que puedan explicarlos convincentemente. Girard lo explicaba de la siguiente manera:

"La plaga sigue viva como tema literario, en un mundo cada vez menos amenazado por epidemias reales. El hecho resulta menos sorprendente cuando nos damos cuenta de que los aspectos médicos de la enfermedad nunca fueron esenciales; en realidad siempre jugaron un rol menor, sirviendo sobre todo como un disfraz para un mucho mayor miedo que la 
ciencia nunca sería capaz de conjurar. Ese miedo sí está todavía con nosotros y sería un error considerar la presencia de la plaga en nuestra literatura como una suerte de rutina formal" (1974: 845).

Es por ello que varios géneros contemporáneos han incorporado algunas de las mecánicas de las narrativas de la plaga en tanto que ofrecen una clave para poner en escena la extensión exponencial y descontrolada de una amenaza sistémica. De un modo paradigmático, las narraciones basadas en la figura del zombi -o variaciones similares - han incorporado la dimensión del contagio epidémico con una explicitud que estaba exenta en las figuraciones clásicas del zombi o del monstruo. En el filme 28 días después (Boyle, 2002), la catástrofe se origina en Reino Unido cuando un grupo de activistas libera a un grupo de primates con los que se estaba experimentando con una variante de la rabia: la facilidad del contagio y su corto periodo de incubación hace que en menos de un mes casi toda la población se transforme en seres desprovistos de más voluntad que la furia de matar. En Soy leyenda (Lawrence, 2007) es una mutación del virus del sarampión ensayada como cura contra el cáncer la que convierte a casi toda la población en seres monstruosos, violentos y agresivos. Así pues, en ambos casos es el desarrollo experimental de un virus, con el objetivo de generar una vacuna, el que desencadena el estallido de una infección masiva: la tecnología de la inmunidad, por tanto, como factor crucial de la catástrofe.

Ese giro es sin duda relevante porque ambas películas se enmarcan en el proceso de revitalización, durante la década del 2000, de la figura del zombi como clave cultural para abordar algunas de las contradicciones fundamentales de las sociedades contemporáneas que retomaban, aunque desde parámetros nuevos, la iconografía zombi que en décadas anteriores habian fijado las películas precursoras de George A. Romero La noche de los muertos vivientes (1968), El amanecer de los muertos (1978) o El día de los muertos (1985). Las películas de Romero eran ya legibles como metáfora de la descomposición y envilecimiento de la sociedad de consumo norteamericana, que sólo podía desembocar en el colapso social y en el estallido de formas de violencia de difícil inteligibilidad (Pérez Ochando, 2013a).

En su ya clásico texto sobre la ciencia ficción, Sontag (1996) proponía la idea de "imaginación del desastre" que, a través de la narración de 
situaciones catastróficas, ponía en escena miedos y angustias en torno a la vulnerabilidad de nuestras instituciones, sistema social y formas de vida. Sin duda, en su deriva actual, las ficciones zombi participan de esa imaginación del desastre explorando insistentemente las posibilidades narrativas del colapso social. De ese modo, construyen una sintaxis narrativa para canalizar, pero también para amplificar, las angustias y miedos en torno a la amenaza de derrumbe radical del sistema en un contexto de crisis social y económica.

Pero a la vez, las ciudades hipermodernas tomadas y arrasadas por hordas de zombis que pueblan estas ficciones exigen un ejercicio de imaginación política que permita reimaginar las formas posibles de vida en una situación de colapso radical, en la que la tecnología y las infraestructuras básicas han dejado de ser operativas. Es por ello que algunas de estas ficciones absorben, aunque de un modo desplazado, algunos de los presupuestos de las filosofías del decrecimiento y la autosuficiencia: las comunidades capaces de generar por ellas mismas su energía, su alimentación y sus condiciones de reproducción serán aquellas que tengan más oportunidades de sobrevivir en un contexto social de colapso (Taibo, 2014). Especialmente llamativas a este respecto son las primeras páginas de Apocalipsis Z. El principio del fin (Loureiro, 2011), en las que el protagonista y narrador explica al lector, ante los continuos fallos del sistema eléctrico de su ciudad, sus planes para hacer del lugar en el que vive un espacio autosuficiente energéticamente, a través de placas fotovoltaicas y acumuladores: esa autosuficiencia es la que, en las semanas siguientes, le permitirá sobrevivir al apocalipsis zombi.

Estas ficciones ponen en relato el pánico a un derrumbe del sistema, pero a la vez algunas de ellas operan como verdaderos laboratorios imaginarios en torno a las formas de vida posibles en una situación de colapso: el Nueva York tomado por la hierba y los animales salvajes de Soy Leyenda, la Atlanta devastada pero reverdecida de The Walking Dead (Kirkman y Moore, 2004-2014) o incluso la Barcelona deshecha y recorrida por un ciervo en Los últimos días (Pastor y Pastor, 2013) son algunas de las imágenes más evocadoras y hermosas de las ficciones del colapso contemporáneas. Porque más allá de la destrucción, puede vislumbrarse en ellas la potencia de nuevas formas de vida. 
Imagen 1. El Nueva York tomado por la vegetación de Soy leyenda (Lawrence, 2007)

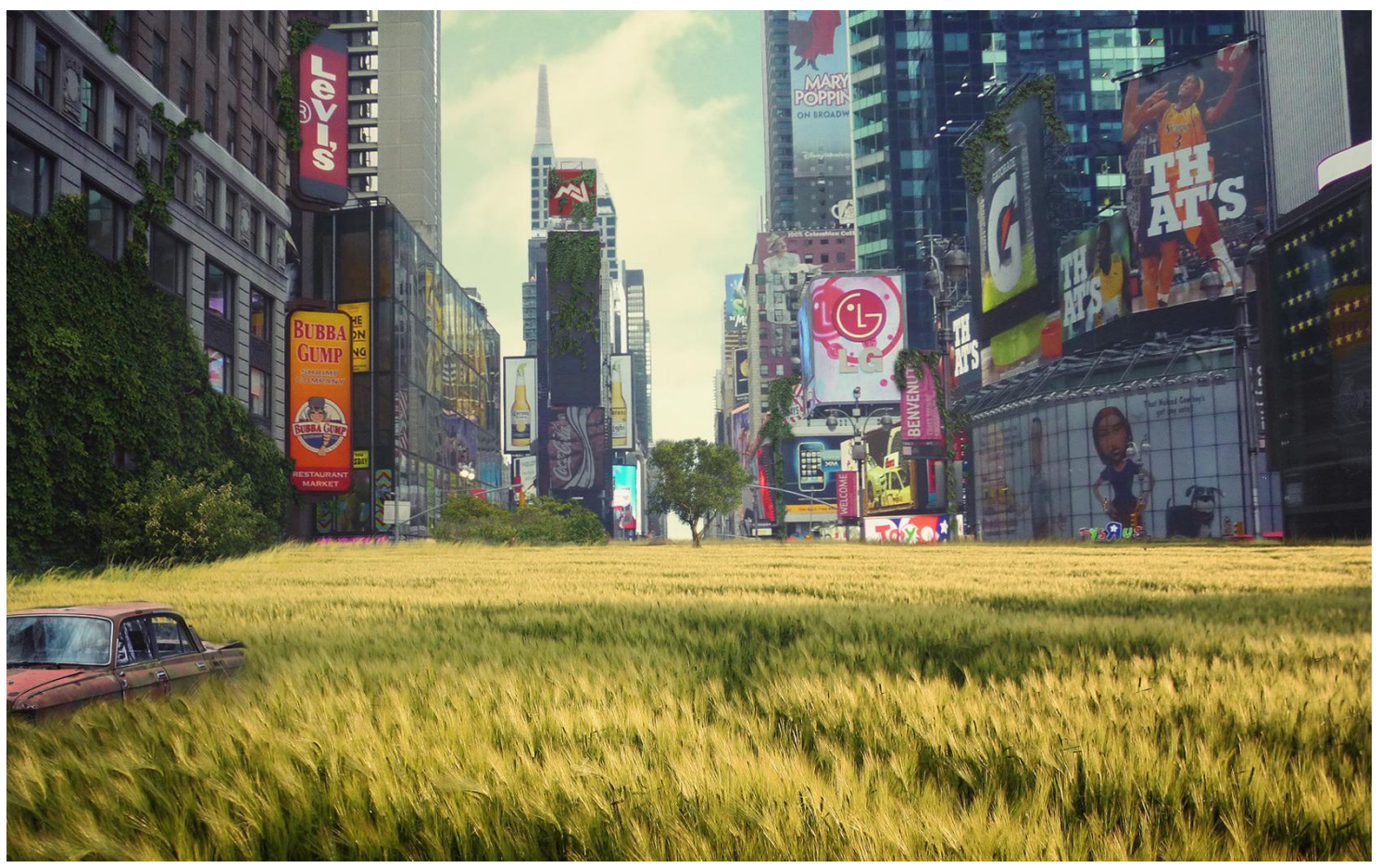

El apocalipsis constituye, de hecho, una situación narrativa que obliga a repensar radicalmente el funcionamiento de la comunidad, sus leyes internas y sus lógicas de cohesión y supervivencia, en una situación en la que ya no son válidas la mayoría de las lógicas pre-apocalípticas. Podemos hablar, en ese sentido, de la producción de un "estado de excepción narrativo" ${ }^{3}$ que suspende en el ámbito de la ficción las leyes del derecho, la moral y la costumbre obligando a los personajes - y a los lectores o espectadores- a replantearse categorías básicas de las relaciones de convivencia y a redefinir en un contexto de amenaza extrema y violencia generalizada las legitimidades sociales y las opciones morales posibles.

Muchas de estas ficciones ponen en relato, de hecho, la necesidad de reconstruir y reinventar las formas comunitarias en un contexto de peligro exterior máximo y en las que las lógicas e instituciones que sostenian las formas anteriores de lo colectivo se han hecho trizas. Pueyo (2013) ha señalado la función que cumplen en las narraciones

\footnotetext{
${ }^{3}$ El concepto de "estado de excepción narrativo" surge en relación con los estudios de Giorgio Agamben (1999 y 2000), quien localiza el "estado de excepción" como una de las matrices fundamentales de las biopolíticas contemporáneas
} 
postapocalípticas contemporáneas la acampada y la asamblea, como espacios de imaginación y problematización de las nuevas formas de comunidad en un contexto de derrumbe de la institucionalidad: "en el escenario sin regular del post-apocalipsis (...) obtener una respuesta exige implementar mecanismos conciliares, rutinas asamblearias e instrumentos improvisados de democracia directa" (ibídem: 33).

Es por ello que algunas de estas ficciones de la catástrofe se acercan, en algunos momentos, al funcionamiento del existencialismo literario. No solo por la reflexión que algunas de ellas articulan en torno a los límites de la vida humana y el sentido posible de la existencia, sino sobre todo por su mecánica narrativa. Del mismo modo que en los dramas y ficciones de Jean Paul Sartre los personajes se ven a menudo obligados a tomar decisiones en situaciones de conflicto moral irresoluble, los personajes de The Walking Dead, inmersos en el apocalipsis zombi, se ven confrontados a dilemas que les obligan a replantearse el valor de nociones como "piedad", "solidaridad" o "asesinato", redefiniendo constantemente los propios límites de lo humano. A modo de ejemplo, en la cuarta temporada de la serie una epidemia de gripe asola la cárcel en la que el grupo protagonista trata de construir una nueva comunidad $^{4}$. En ausencia de medicamentos y en condiciones de precariedad extrema, la gripe se vuelve mortal y cada infectado por ella se convierte, de hecho, en una amenaza de muerte para los demás: más amenazante si cabe que los zombis que rodean la prisión, pues en el caso de la gripe no es necesario el contacto físico ni la violencia para producir un contagio que, por tanto, es invisible y más difícilmente controlable. En ese contexto de excepción, ¿resulta moralmente legítimo ajusticiar a los enfermos de gripe como se hace con los zombis?, ¿qué moral debe prevalecer, la que resalta la condición humana de los enfermos o la que pone el acento en el riesgo que suponen para el bien común?

Así pues, en algunos casos, el estado de excepción narrativa se utiliza para desencadenar dinámicas deliberativas o situaciones dilemáticas que obligan a desnaturalizar el sentido común y las ideas y nociones

\footnotetext{
4 "Parece que al final han ganado los comunistas" le dice Diana Monroe a Rick Grimes al mostrarle el funcionamiento de la zona segura de Alexandria en The Walking Dead. Se trata de un juicio positivo, muy insólito en la cultura masiva norteamericana, que alude a la necesidad de construir una nueva sociedad regida por patrones no capitalistas. El apocalipsis zombi, pues, como una situación de crisis total que exige de replanteamiento general de las relaciones sociales.
} 
recibidas en torno a las relaciones humanas. Sin embargo, en la mayoría de los casos, el estado excepción narrativa abre la puerta a procesos de militarización y legitimación de formas autoritarias de poder que descartan los procedimientos democráticos a favor de poderes centralizados y autolegitimados para ejercer la violencia ${ }^{5}$. Es el giro que experimenta la trama en The Walking Dead al final de su segunda temporada: tras un tiempo en el que el grupo había funcionado de un modo relativamente asambleario y las decisiones cruciales eran tomadas por votación, lo que no dejaba de generar vacilaciones, tensiones y disputas en el interior del colectivo, tras un ataque masivo, el protagonista Rick Grimes decide imponer su ley sobre la comunidad: "Venga, ¿podéis hacerlo mejor? Ahí tenéis la puerta. Pero que esto quede claro: si os quedáis, lo de la democracia se ha terminado" (2012, 2x13). Del mismo modo, la comunidad artificial creada por el Gobernador y basada en la disciplina interna y la militarización social escenifica de forma crítica la tendencia a la fascistización generada por la conversión en regla del estado de excepción ${ }^{6}$.

De hecho, muchas de estas ficciones inmunitarias tienden a naturalizar esa respuesta antidemocrática a la situación de excepción y a generar un clima emocional que la justifica y legitima, dando por sentado que "la manera de responder a situaciones críticas es fortalecer el grado de control de las autoridades y suspender derechos humanos básicos" (Ferrer Ventosa, 2015: 190).

\section{EL CUERPO ZOMBI Y EL VACÍO SOCIAL}

Esa tendencia a naturalizar el estado de excepción, que abarca por igual a las ficciones epidémicas, a los relatos postapocalípticos y a las narraciones de catástrofes, cobra un sentido especial cuando lo que se dirime son las medidas a tomar sobre el cuerpo humano. Se ha señalado recurrentemente el carácter de metáfora global del cuerpo zombi. Pero deberíamos preguntarnos, ¿metáfora de qué? En sus orígenes, las imágenes culturales del zombi surgieron en el interior de un imaginario

\footnotetext{
${ }^{5}$ Hanson (2006) subraya el rol del héroe masculino y blanco en la solución de la catástrofe cinematográfica y en la consolidación de valores conservadores como el individualismo y la masculinidad tradicional.

${ }^{6}$ La excepcional novela $Z$ de Max Brooks (2015) disecciona magistralmente los procesos de disciplinamiento y militarización social que siguen, en su universo narrativo, a los estallidos zombi (Peris Blanes, en prensa).
} 
colonial $y$, por tanto, eran inseparables de una política racista de segregación y deshumanización de las poblaciones colonizadas (Domínguez Leiva, 2013: 5-6) ${ }^{7}$. Pero el zombi contemporáneo, aun manteniendo su vinculación con los imaginarios racistas, presenta un carácter fuertemente ambivalente y polisémico ${ }^{8}$, lo que le lleva a encarnar angustias y ansiedades de muy diferente tipo, sin duda relacionadas con el carácter difuso y derivativo (Bauman, 2007) de los miedos a los que estas representaciones tratan de responder.

No pocos analistas han visto en la figura del zombi una metáfora aunque desplazada - de las lógicas de la alienación, la estandarización y la desindividualización que caracterizan al consumismo contemporáneo. Los zombis, de hecho, muestran una pulsión repetitiva por devorar carne humana, totalmente desconectada de su necesidad biológica. Esa urgencia por satisfacer un hambre inmotivado por la necesidad física supone, pues, un exceso, que efectivamente puede funcionar como metáfora del consumo. Esta lectura del zombi halla su mejor apoyatura en El amanecer de los muertos que ocurre, en buena parte del metraje, en el interior de un centro comercial. Las imágenes de los zombis caminando a sus anchas por los pasillos, las escaleras mecánicas y los escaparates apuntan inevitablemente a la continuidad entre el zombi y el sujeto consumista. Uno de los personajes, al verlos, señala: "Es un reflejo inconsciente. Un vago recuerdo de lo que tenían costumbre de hacer. Ese lugar jugaba un papel importante en sus vidas" (1978).

\footnotetext{
${ }^{7}$ En torno a la relación entre la figura del zombi, el imaginario racial y el esclavismo, se puede consultar Lauro (2015) y Moreman y Rushton (2011).

${ }^{8}$ Esa polisemia es la que permite su uso como saboteador y deconstructor de la tradición que describe Molina Gil (2015) en su análisis de las reescrituras z de los clásicos.
} 
Imagen 2. Zombis en el centro comercial en El amanecer de los muertos (Romero, 1978)

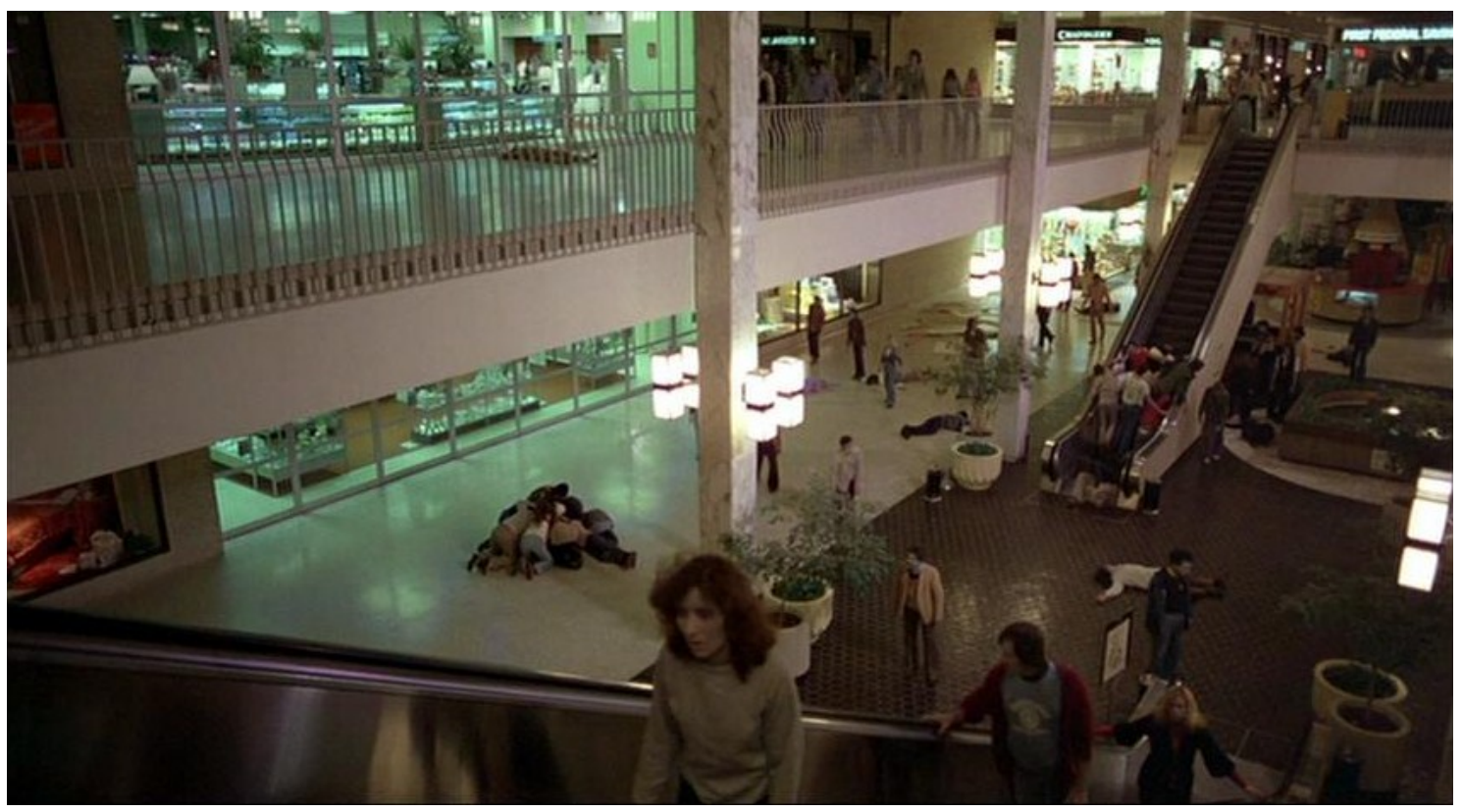

Más que eso, los zombis aparecen identificados visualmente a los maniquies que pueblan las tiendas y a los muñecos mecánicos de las tiendas de juguetes. La continuidad entre los movimientos repetitivos e inmotivados de ambos alude directamente al vaciamiento de la subjetividad que produce la lógica del consumo contemporáneo, y que los zombis llevarian a su extremo ${ }^{9}$.

Pero al mismo tiempo, la amenaza del zombi se basa sin duda en su carácter masivo y multitudinario. La torpeza y lentitud del zombi, su ausencia de perspicacia e inteligencia hacen que solamente sea realmente peligroso cuando la masa zombi toma la forma de una avalancha. El zombi contemporáneo, de hecho, carece de individualidad, lo que lo separa de otros monstruos aristocratizantes y nobles en su pulsión destructiva como el vampiro o el alien atribuyéndoseles una capacidad de comunicación sensorial similar a la de las hormigas mediante la cual podrian actuar como un organismo colectivo, y no tanto como una suma de individualidades que, por otra parte, carecerian de deseo y espesor subjetivo. En ese sentido, no es difícil

\footnotetext{
${ }^{9}$ De un modo inteligente, la novela zombi De Madrid al Zielo (Zamora Llorente, 2015) atribuye esos rasgos de estandarización y automatismo a la población urbana de Madrid dias antes del estallido del apocalipsis zombi, estableciendo una continuidad evidente entre el zombi y las características del sujeto urbano contemporáneo.
} 
aventurar que las narrativas zombi contemporáneas ponen en relato miedos y angustias en torno a la presencia de las masas y multitudes incontrolables en el mundo social contemporáneo. En ese sentido, parecieran gestionar miedos en torno a la disolución del individuo en la masa, pero también en torno al poder transformador - destructivo pero también constituyente- de la multitud ${ }^{10}$.

Pero ¿qué tipo de masa o multitud pueden encarnar las legiones de zombis que pueblan estas narrativas literarias o audiovisuales?, ¿qué tipos de cuerpos se dan cita en ellas?, ¿qué angustias y miedos sociales se proyectan sobre ellos? El cuerpo zombi es sin duda un cuerpo amenazante que a veces, en su propio desvalimiento $y$ deshumanización, puede llegar a aludir a figuras de radical precariedad vital. Es por ello que, en no pocas de estas ficciones se puede identificar la no muerte del zombi con una versión extremada de las vidas precarias de los excluidos del capitalismo contemporáneo ${ }^{11}$. En no pocos discursos públicos de la España de la crisis económica se ha trazado una relación directa entre la masa de desempleados generada por el estallido de la burbuja económica y la figura del zombi: desorientados, confundidos, en estado de shock y vaciados de cualquier capacidad de agencia, los excluidos del neoliberalismo son conceptualizados como meros espectros sin voluntad.

Sin embargo, más que alentar a la solidaridad o la empatía ${ }^{12}$, la representación visual del zombi se ha concentrado en su carácter abyecto y desasosegante, como respuesta visual a la angustia social ante una población desestructurada y amenazante ${ }^{13}$. Efectivamente, el cuerpo zombi, degradado, abierto y en descomposición parece funcionar como metáfora visual del desmembramiento y la degradación social. Como puede verse, en las imágenes de la novela gráfica The

\footnotetext{
${ }^{10}$ Probablemente ninguna película haya llevado tan lejos esa idea como La tierra de los muertos vivientes (Romero, 2005) que propone una lectura política del zombi como excluido radical y de la potencia de la multitud de excluidos como fuerza posible de transformación.

${ }^{11}$ Para Domínguez Leiva, por ejemplo, "la masa neo-zombi evoca concretamente el hormigueo subterráneo del lumpen-proletariado" (2010: 22).

${ }^{12}$ Lo señala Canavan: "dado que los zombis marcan la frontera entre vida y no-vida, su evocación no provoca solidaridad, sino pánico racial" (2010: 433).

${ }^{13}$ Pérez Ochando (2013b), en su tesis doctoral sobre el cine de terror contemporáneo, titulada no por azar La ideología del miedo, lee la emergencia del cine de zombis en la última década como un efecto de la ideología de la estigmatización de las masas por la gobernabilidad neoliberal.
} 
Walking Dead los límites del cuerpo zombi aparecen a menudo desdibujados, difícilmente diferenciables de su exterior. Se trata, a todas luces, de un cuerpo abyecto, que presenta rasgos humanos pero sometidos a un proceso de degradación radical y convertido en mera materia biológica despojada de voluntad y sentido. De hecho, más que cuerpos, los zombis parecen ser pura carne despojada de sentido y de organicidad; más que ubicarse en un lugar intersticial entre la vida y la muerte, los zombis contemporáneos parecen habitar más bien esa zona de suspensión del sentido que es la nuda vida, tal como la define Agamben (1999): una vida reducida a la mera existencia biológica a la que cualquiera puede dar muerte sin cometer un homicidio.

Imagen 3. Zombi de The Walking Dead (Robert Kirkman, dibujo Tony Moore)

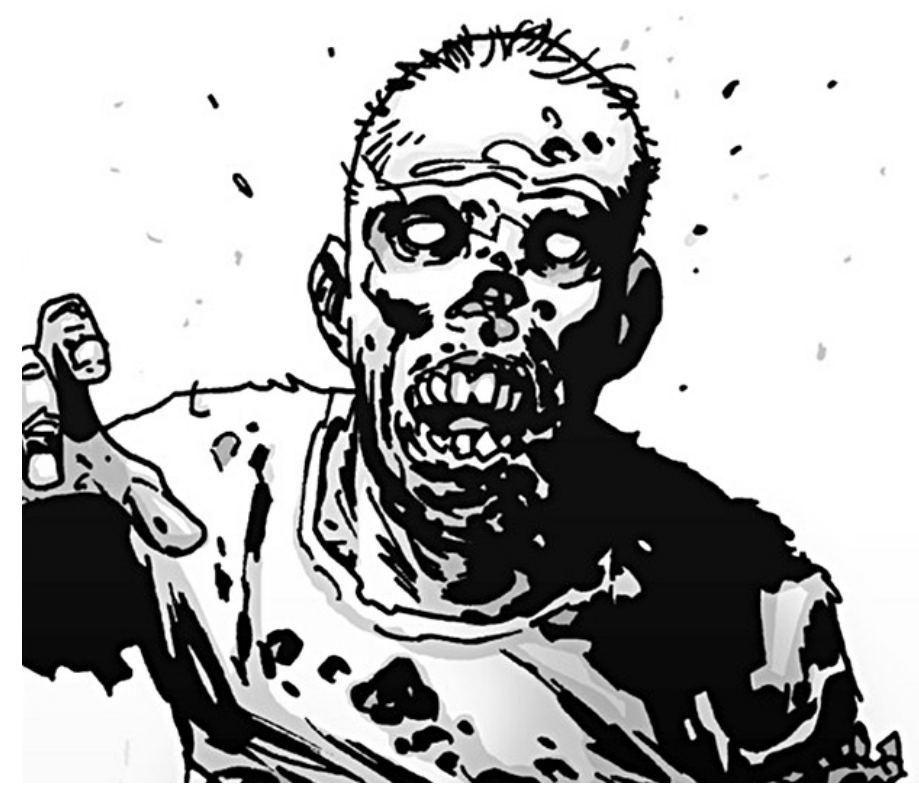

En ese sentido, la imagen del zombi canaliza culturalmente la fantasía social de un otro extremadamente degradado y en el límite de lo que consideramos lo humano y sirve a estas narraciones para poner en relato la relación problemática con los cuerpos ajenos y marcados por la degradación extrema. Frente a la seducción del vampiro, el cuerpo del zombi despierta una repulsión sin matices. Parece, pues, más vinculado al cuerpo del excluido radical -el mendigo, el drogodependiente, el migrante, el sin techo...-, gangrenado y a punto de la descomposición. En ese sentido, no hay duda de que el cuerpo zombi es portador de un "significante enfermo" (Wynter, 1995) que lo marca y separa de la 
humanidad sana para la cual se ha convertido en amenaza. Carente de cualquier rasgo de seducción o atracción, el cuerpo del zombi es un deshecho social, un resto excremencial cuya propia inorganicidad lo convierte en amenaza para una descomposición global del mismo sistema que lo excluye. En ese sentido, las ficciones zombi construyen una sintaxis narrativa eficaz para canalizar el temor a las bolsas de población excluida de nuestros sistemas sociales, o, como se ha dicho, la angustia xenófoba ante la inmigración en una era "posracial" (Watts, 2014).

Los primeros capítulos de Fear the Walking Dead (Kirkman y Erikson, 2015) llevan al extremo esa identificación entre el cuerpo zombi y el cuerpo del excluido, situando los primeros brotes zombis en una iglesia abandonada que un grupo de adictos a la heroína utilizan para consumirla. El brote de la epidemia zombi, pues, surge desde ese espacio de abyección y caída del sentido que es, para la imaginación dominante, la adicción a la heroína. Pero el primer capítulo va más allá: uno de los protagonistas, Nick Clark, es adicto y posee todos los rasgos tipificados del yonqui. Por ello sus andares torpes, su pelo grasiento y su rostro sudoroso hacen que, en diferentes momentos se le confunda visualmente con un zombi e incluso, en un momento crucial, las autoridades lo segreguen de su familia y de su comunidad para recluirlo con otros sujetos potencialmente infectados. Antes de eso, en la búsqueda que su madre y su padrastro realizan por las calles de una ciudad de Los Ángeles anterior al apocalipsis, buena parte de los zombis que empiezan a poblar las calles son interpretados por ellos, desde la lejanía, como drogodependientes. El espectador vacila: ¿esas figuras que pululan por las calles sin aparente rumbo ni sentido son los yonquis preapocalípticos de una ciudad en crisis o las primeras manifestaciones del apocalipsis zombi que está por venir? Lo importante, con todo, es que en esos primeros capítulos no hay forma de diferenciar visualmente al zombi de ese excluido radical que es el adicto a la heroína en la ciudad postindustrial. Yonqui y zombi aparecen, pues, producir una similar caída del sentido, algo que Kristeva relacionaba con el cuerpo abyecto (1988).

Sin duda, esa condición liminar, perturbadora no solo de la identidad, sino de la estabilidad de las categorías con las que producimos sentido en lo social, acerca el cuerpo zombi no solo a la figura del yonqui, sino a la forma en que se perciben y construyen socialmente las figuras del 
indigente, el sin techo o ciertas formas de migración de alta precariedad. En Diario de los muertos (Romero, 2007), la voz en off explica así el estallido del apocalipsis: "Todo esto lo empezó un grupo de inmigrantes ilegales, que por error fueron tomados por muertos". De nuevo los excluidos del capitalismo contemporáneo, los habitantes del "vacío social", es decir, los habitantes de esas zonas de inestabilidad social que han dejado de ser legibles desde los cuadros interpretativos normalizados, emergen. Tal y como señala Barel ${ }^{14}$ :

"El vacío social es lo que ocurre en ciertas partes del cuerpo social que, o bien no son reconocibles ni visibles para otras partes del cuerpo social (...) o bien son sentidas por ellas como una fuente indistinta y confusa de peligros y amenazas" (1982: 160).

Invisibles o amenazantes, los sujetos que habitan esas zonas de inestabilidad social y de nula institucionalidad quedan fuera de la visibilidad social o se incluyen en ella como un peligro potencial. Proponemos, pues, que las narrativas zombi (y similares) ofrecen una figuración que pretende cifrar ese vacío social y las vidas precarias de los sujetos que lo habitan. Pero al hacerlo, estas tramas culturales contribuyen a extender una imagen estigmatizada y amenazante, poniendo en relato la necesidad de frenar el peligro que entraña esa proliferación de cuerpos extraños para la comunidad.

\section{Miedo DERIVATIVO Y NECROPOLÍTICA: LA CULTURA DEL SHOCK}

Haciéndolo, contribuyen decisivamente a la consolidación de lo que Bauman, siguiendo a Hugues Lagrange, denomina "miedos derivativos" (2007): aquellas formas del miedo que nos hacen responder ante una sensación difusa de inseguridad y de vulnerabilidad como si estuviéramos ante un encuentro real con el peligro. Eso es lo que denomina la "capacidad autopropulsora" (ibídem: 12) del miedo derivativo que responde a menudo con violencia inmunitaria a situaciones que, en rigor, no la exigen. Dicho de otro modo, las narrativas zombi, que llevan al extremo las lógicas de la ficción inmunitaria, potencian y dan una apoyatura visual y narrativa a los miedos sociales en torno a los excluidos, legitimando emocionalmente, de esa forma, estrategias de segregación, políticas de separación y

\footnotetext{
${ }^{14} \mathrm{He}$ de agradecer a Gabriel Gatti la introducción a las teorías de Barel, que él mismo ha desarrollado en Gatti, 2015.
} 
discriminación $y$, en general, una respuesta violenta frente a la población que habita ese vacío social.

Efectivamente, la construcción del excluido como monstruoso y abyecto se anuda a un uso del estado de excepción narrativa que legitima prácticas de represión o segregación social que difícilmente podrian justificarse en una situación de normalidad. Las secuencias de ajusticiamiento de zombis se hallan tan normalizadas en estas narraciones que incluso el hecho de matar a un infectado (mordido) todavía vivo y que, por tanto, sigue siendo humano, no es considerado un asesinato, sino más bien un acto de piedad, una forma leve de violencia necesaria para conjurar el peligro de la infección global. En Diario de los muertos (2007), la película más reflexiva de George A. Romero - pensada como un diario audiovisual del apocalipsis-, la voz en off señala que "en tiempos de guerra asesinar es fácil" o "esto es un diario de la crueldad, y en tiempos de guerra, cuando el enemigo puede ser matado como este cabrón o este cabrón, la crueldad se vuelve justificada". Los zombis, pero también los infectados que pronto lo serán, encarnan pues en estos relatos la vida que puede y debe ser matada en condiciones de legitimidad moral.

En sus estudios sobre la emergencia histórica del racismo, Foucault (1992) mostró cómo en la modernidad la función del racismo consistió precisamente en eso, en regular la distribución de la muerte y en legitimar el derecho del Estado de matar, estableciendo cesuras en la población que distribuían la condición de matable o no matable. El racismo se constituyó, pues, como un dispositivo para generar "la condición de aceptabilidad de la matanza" (ibídem: 90). Para Mbembe (2011), en su análisis del racismo, el sustantivo "negro" servía precisamente para cuestionar la humanidad del sujeto y señalar la posibilidad animal de la que era portador ${ }^{15}$.

Un señalamiento que, sin duda, se podría aplicar a la figura del zombi. Más allá del dispositivo racial de la modernidad, la omnipresencia cultural del zombi parece textualizar un proceso de redistribución de lo matable y de la vida humana desechable, que normaliza

\footnotetext{
${ }^{15}$ En su Crítica de la razón negra (2016), Mbembe lanza la profecía de un devenir negro del mundo, en la que proyecta al presente los sufrimientos de millones de personas, privadas por la esclavitud de nombre, familia y habla, convertidos en objeto, mercancía y hombresmoneda de cambio. Podríamos aventurar que las representaciones del apocalipsis zombi dan una apoyatura visual a este devenir negro.
} 
imaginariamente unas renovadas "condiciones de aceptabilidad de la matanza". Si, tal como anteriormente se ha planteado, el cuerpo del zombi metaforiza el cuerpo del excluido $y$, en su abyección, concentra las angustias inmunitarias de la sociedad normalizada frente a la presencia de cuerpos no higienizados ni reglados, la violencia legítima frente al zombi supondría, en cierto sentido, una forma de legitimación narrativa de la violencia - del tipo que sea-contra el excluido.

No se trata, desde luego, de que estas películas, novelas y series argumenten la necesidad de matar, segregar o reprimir a mendigos, excluidos económicos o migrantes. Sin embargo, generan los mimbres emocionales para responder a una situación de excepción con una violencia extrema hacia esos cuerpos degradados y conceptualizados como portadores potenciales de amenaza. En su estudio sobre el concepto de "necropolítica", Mbembe lo explica así:

\begin{abstract}
“Examino las trayectorias a través de las cuales el estado de excepción y la relación de enemistad se han convertido en la base normativa del derecho de matar. En estas situaciones, el poder (que no es necesariamente estatal) hace referencia continua e invoca la excepción, la urgencia y una noción 'ficcionalizada' del enemigo. Trabaja para producir esta misma excepción, urgencia y enemigos ficcionalizados" (2011: 21).
\end{abstract}

Esa construcción ficcional del enemigo aparece claramente articulada al dispositivo inmunitario en una importante secuencia de La guerra mundial $Z$ (Foster, 2013), versión cinematográfica de la novela de Max Brooks. En ella, toda la humanidad ha sucumbido al colapso, con la notable excepción de Israel que, ante un signo más bien débil de amenaza - la palabra zombi escrita en un email interceptado- decide construir un muro capaz de contener cualquier intrusión del exterior. Vale la pena reproducir el diálogo:

"- ¿Levantaron un muro por un email en el que aparecía la palabra zombi?

-Bueno, dicho de ese modo yo también sería escéptico. En los años 30 los judíos se negaron a creer que los podian enviar a campos de concentración. En el 72 nos negamos a creer que nos iban a masacrar en los Juegos Olímpicos. En septiembre de 1973 vimos movimientos de tropas árabes y creímos que no representaban una amenaza. Un mes después nos atacaron y casi nos echan al mar. Así que decidimos hacer un cambio. (...) El décimo hombre. Si nueve de nosotros, ante la 
misma información, llegamos a la misma conclusión, el décimo hombre está obligado a disentir. Y da igual lo inverosímil que pueda parecer, el décimo hombre tiene que indagar dando por supuesto que los otros se equivocan. (...) Dado que todos suponían que la mención a los zombis era un pretexto para otra cosa yo empecé a investigar partiendo del supuesto de que cuando decían zombis querían decir zombis.

-El paciente cero era de la India.

-Ese es el problema. Hay tantas fuentes potenciales en juego que nadie sabe dónde empezó. El tráfico de órganos en Alemania, extraños ejemplos de conductas violentas en las penínsulas asiáticas, y entre tanto, la plaga zombi se sigue extendiendo. Esto es lo que hicimos [señala al muro]: las puertas de la salvación de Jerusalén. Dos de los diez portales con los que el Israel fortificado se ha protegido"

Así pues, el pueblo israelí habría depurado tanto sus mecanismos inmunitarios con el paso del tiempo que habría conseguido repeler la amenaza a través de un enorme muro rodeando la ciudad de Jerusalén. Es por ello que la ciudad se convierte en un espacio de refugio para los humanos no infectados, independientemente de su religión y cultura, pero los zombis del exterior llegan a ser tan numerosos que consiguen finalmente sortear el muro y atacar a esa comunidad multiétnica y multirreligiosa que se había refugiado en la ciudad. La elección de Israel no es, desde luego, baladí. No solo, como se argumenta en la película, por su larga tradición de hostigamiento, sino también por la intensidad de sus políticas de seguridad, segregación y violencia fronteriza desplegadas en el contexto del conflicto palestino-israelí, al que película alude así, de forma indirecta pero explícita. Quizás sea aventurado afirmar que los zombis que rodean la ciudad de Jerusalén suponen una ficcionalización deshumanizadora del enemigo palestino, pero las imágenes de los zombis escalando el muro de Jerusalén remiten directamente a la de los muros que separan Cisjordania y Gaza del Estado de Israel. Por una parte, se genera una experiencia narrativa en que esa forma de separación y segregación aparece legitimada emocionalmente. Por otra, se argumenta claramente que los muros no son suficientes y harían falta políticas inmunitarias más eficaces para frenar la amenaza que supondría ese pueblo, caracterizado como subhumano, que hostiga al israelí. 
Más allá del caso concreto, la figura del muro se ha convertido en los últimos tiempos en uno de los símbolos globales de las políticas inmunitarias: de las vallas de Melilla al muro de Trump, parece ser la respuesta más simple a las tensiones producidas por los flujos de migración, y el modo más evidente de responder a la amenaza imaginaria del otro social que habitaría más allá de la frontera. Por ello, lo relevante es que la película trata de comprometer emocionalmente al espectador con la forma más despiadada de la lógica inmunitaria, legitimando narrativamente una política de segregación espacial que sería probablemente rechazada por el mismo espectador en un contexto de normalidad. Esta es, sin duda, la gran potencia de lo que hemos denominado el estado de excepción narrativa: producir un shock en el lector/espectador que haga posible su alineamiento emocional con las nuevas modalidades de la represión inmunitaria y con las nuevas condiciones de aceptabilidad de la violencia. Un alineamiento, sobra decirlo, que nunca se produciría a través de una discusión o argumentación racional.

En este sentido, las ficciones inmunitarias forman parte de lo que podriamos denominar una cultura del shock, siguiendo los planteamientos de Klein (2007) en su caracterización del capitalismo contemporáneo. Klein argumenta que la implantación de las políticas neoliberales durante las últimas cuatro décadas ha necesitado, en la mayoría de los casos, de la creación previa de un estado de shock en la población: solo en el estado de confusión y desorientación social que sigue a un estado de shock colectivo - como el generado por un desastre natural, un atentado terrorista, un golpe de estado o una crisis económica, etc.- sería posible llevar a cabo las reformas económicas, legislativas y laborales que exige la doctrina neoliberal, que precisamente por ello Klein bautiza como la doctrina del shock. Una cultura del shock es, por tanto, aquella que lejos de buscar una reflexión pausada en torno a los problemas sociales del mundo contemporáneo los inserta en tramas e imágenes que golpean con fuerza al espectador y lo desorientan a partir de situaciones excepcionales que lo llevan a un punto máximo de tensión. Es en ese estado de alteración en el que el espectador acepta y se compromete emocionalmente con conductas y argumentos que en ningún caso aceptaría fuera de ese estado.

Estas ficciones, no solo producen figuraciones estigmatizadoras y distorsionadas que replican la lógica del racismo histórico, sino que 
preparan emocionalmente a lectores y espectadores para dar una respuesta reaccionaria y violenta a una catástrofe que no va a suceder; haciéndolo alimentan un miedo que puede derivar en formas de violencia social no necesariamente iguales a la que estas ficciones muestran, pero sí paralelas y equivalentes funcionalmente. Miedo derivativo que legitima y promueve formas violentas de inmunidad social y que contribuye a extender el estado de shock social con el que parece haberse comprometido parte de la cultura masiva contemporánea.

\section{DE PURGAS Y MÁSCARAS: FICCIONES CRÍTICAS EN LA CULTURA DEL SHOCK}

Y, sin embargo, también hay ficciones contemporáneas conscientes de ese alineamiento de la cultura masiva con las lógicas inmunitarias y con la cultura del shock que tratan de articular un discurso crítico, o al menos distanciado, en el que esas mismas lógicas aparezcan representadas y desnaturalizadas. Me referiré, en lo que sigue a dos de ellas, por su carácter ciertamente insólito y su repercusión global ${ }^{16}$.

La purga es una trilogía cinematográfica formada por La noche de las bestias (2013), Anarquía (2014) y Election Year (2016). Escrita y dirigida por James DeMonaco narra un futuro cercano en el que unos Nuevos Padres Fundadores han refundado políticamente Estados Unidos e impuesto un funcionamiento político autoritario en el que la tasa de desempleo y la delincuencia se han reducido al $1 \%$ mientras el crecimiento económico es el más alto y sostenido de la historia. De acuerdo al relato oficial, esos excelentes datos se deben al carácter catárquico de la purga anual, un evento en el que todo crimen conocido es legal, y todos los servicios públicos de mantención del orden (especialmente policia, bomberos y hospitales) quedan suspendidos. Se trata de un estado de excepción efectivo en el que cualquiera puede matar a cualquier otro con el objetivo de liberar las pasiones autodestructivas y confinar la violencia social a una única noche del año. En la práctica, sin embargo, la purga se convierte en un efectivo método de segregación y exterminio social y en un formidable negocio para las empresas de seguridad. Efectivamente, las clases altas pasan la noche

\footnotetext{
${ }^{16}$ En el caso español, Martínez Fernández (2014) analiza la posibilidad de un uso crítico del shock estético para hacer frente al shock neoliberal.
} 
de la purga encerrados en sus fortalezas, mientras las clases trabajadoras, las personas sin hogar y especialmente la comunidad negra corre el peligro de ser masacrada por sus vecinos o por grupos organizados de jóvenes de clase alta con ganas de vivir la experiencia excitante de la masacre.

La purga es, pues, una película que se presenta como de terror ciertamente comparte alguno de sus estilemas y fórmulas narrativaspero que a medida que avanza su trama va convirtiéndose en una trilogía abiertamente política. Su tema es sin duda la violencia de clase y la utilización del shock generado por el estado de excepción como técnica necropolítica. Efectivamente, a medida que avanza la trilogía se va revelando que la violencia espontánea de vecinos contra vecinos que despierta la suspensión de la ley no es suficiente para los objetivos de control poblacional que persiguen los Nuevos Fundadores. Por ello, es el propio Estado quien se encarga, a través de escuadrones de la muerte, de llegar allí donde la violencia espontánea no llega, organizando el exterminio de pobres, negros, inmigrantes y otros sectores de población que resultan incómodos.

Lo insólito de La purga es que, frente a la tendencia de las ficciones inmunitarias a promover una identificación emocional con aquellos personajes que ejercen la violencia inmunitaria para sobrevivir -los humanos en el apocalipsis zombi, los científicos o militares en el estallido de una epidemia... - la trilogía de DeMonaco narra los acontecimientos desde el punto de vista de aquellos que sufren la violencia de la inmunidad social, de quienes son perseguidos en la noche de las bestias por su condición social o racial y de quienes luchan por acabar con ese estado de excepción anual en el que su vida es matable sin que su muerte constituya un asesinato. De esa forma, sin duda, La purga desnaturaliza la violencia inmunitaria, argumenta en su contra y genera una mirada crítica y emocionalmente refractaria a su lógica de funcionamiento.

Y, sin embargo, la coherencia política de su trama -realmente sorprendente en una película norteamericana de terror-contrasta con el modo en que, en su estética, DeMonaco reproduce las lógicas visuales y narrativas de la cultura del shock y su voluntad de golpear al espectador con estallidos de violencia. Dicho de otro modo, la trilogía lleva a cabo una crítica metafórica pero coherente de las formas contemporáneas de la violencia de Estado y de la utilización del miedo al 
desorden como legitimación de esas formas de violencia; pero al mismo tiempo, el visionado de la trilogía produce en el espectador una experiencia sensorial similar a la de las películas de acción y terror: fascinación por una violencia estilizada y espectacularizada, experimentación de un miedo creciente dosificado a partir de la construcción de 'sustos' e imágenes siniestras... Como señala acertadamente en su análisis Pérez Ochando: "¿cómo podría servir como denuncia de la violencia si ésta constituye su gancho para el espectador?" (en prensa).

La purga, pues, supone una crítica de la violencia inmunitaria desde un lenguaje visual y narrativo similar al de las ficciones inmunitarias: ese es sin duda su límite político y su gran contradicción, pero también su principal atractivo. Una opción diferente es la del capítulo 3x05 de la serie futurista Black Mirror (Brooker, 2016): "La ciencia de matar/Men against fire", que se sitúa en un tiempo y lugar indeterminado, en un periodo de postguerra en el que el ejército está movilizado para acabar con lo que denomina las "cucarachas", conceptualizadas como la amenaza principal de la población y como el principal enemigo a erradicar. En ese contexto, el espectador sigue la historia de Stripe, soldado cualificado y entrenado específicamente para la busca, captura y exterminio de las "cucarachas'" y percibe el ambiente de odio y desprecio inculcado en el ejército contra ellas. Stripe y sus compañeros poseen una tecnología cerebral, denominada la "máscara", que planifica, estudia y ejecuta movimientos estudiados y programados y les ofrece a tiempo real información y comunicación esencial para llevar a cabo sus razzias contra las "cucarachas" con precisión y eficacia. Pero además la "máscara" es también una tecnología que altera y dirige la percepción de los soldados para que perciban a una parte de la población -aquella que el ejército desea exterminar, y a la que ha deshumanizado Ilamándola "cucarachas" - de un modo distorsionado, como humanos degradados con la carne podrida y dientes afilados, incapaces de articular más que gruñidos animales, con un aspecto amenazante y deshumanizado muy similar al que la cultura masiva ha reservado a los zombis. Se trata, pues, de un apoyo perceptivo a la lógica del exterminio, que permite a los soldados matar humanos pensando que no lo son, y percibir a la parte de población exterminable como una amenaza brutal no solo para la comunidad, sino para la propia especie humana. 
La "máscara", por tanto, incide en uno de los aspectos que más ha preocupado a historiadores, sociólogos y pensadores que han abordado las lógicas de represión masiva: ¿cómo es posible poner en funcionamiento una maquinaria sistemática de la violencia que chocaría con los principios más elementales de la empatía y la responsabilidad individual? Muchos han sido los pensadores que han puesto sobre la mesa los procesos de burocratización, fragmentación de la responsabilidad y deshumanización del enemigo que han hecho posibles los exterminios masivos de la modernidad ${ }^{17}$; la 'máscara' condensa todos ellos en una alteración sensorial: el soldado, directamente, deja de percibir al enemigo como humano.

Black Mirror no alude solo a un nuevo funcionamiento de las formas represivas, sino también a una reorganización del mundo sensible desde parámetros nuevos, coherentes con la emergencia de un nuevo orden en el que una parte de la población dejaría de ser percibida como tal. Así, la "máscara" apunta directamente a la colonización de nuestra imaginación por los discursos y ficciones inmunitarias que, desde diferentes lugares -cultura masiva, medios informativos, nuevas formas de difusión imaginaria... - inciden en nuestra percepción del otro social, ofreciéndonos representaciones distorsionadas y mediatizando nuestra posibilidad de percibir o no la existencia ( $y$ la condición humana) de ciertas partes de la población. Colonización imaginaria, mediación perceptiva: la máscara de Stripe es el dispositivo que altera su percepción del otro para hacerlo únicamente reconocible como amenaza deshumanizada. Metáfora de algo que podríamos denominar el reparto inmunitario de lo sensible ${ }^{18}$ que implicaría un reordenamiento de lo visible y lo invisible, de lo audible y lo inaudible, de acuerdo a los criterios de la lógica inmunitaria.

Ambas ficciones representan, problematizan, hiperbolizan y desnaturalizan algunos de los dispositivos inmunitarios que atraviesan nuestra sociedad y la forma en que nuestra experiencia de la realidad se ve intervenida, colonizada y alterada por ellos. Se trata, por tanto, de

17 De hecho, el significante "cucarachas" fue utilizado como mecanismo de deshumanización masiva en el genocidio ruandés por el poder gubernamental hutu que durante años denominó de ese modo a los tutsis, produciendo una separación entre ese conjunto de población y la idea misma de lo humano.

${ }^{18}$ Siguiendo la concepción de Rancière (2009) del "reparto de lo sensible" a través del cual se construye y se reconfigura nuestra experiencia sensible del mundo y se define, en ella, qué elementos son reconocibles (visibles y audibles) y cuáles no. 
ficciones críticas y desnaturalizadoras, pero que por ello mismo necesitan incorporar mecanismos y estilemas de aquello que critican para insertarse en lo que hemos llamado la "cultura del shock", en la que las ficciones inmunitarias hallan su hábitat natural.

Imagen 4. Humano percibido como "cucaracha" debido a la alteración perceptiva de la máscara en la serie Black Mirror 3x05 (2016)

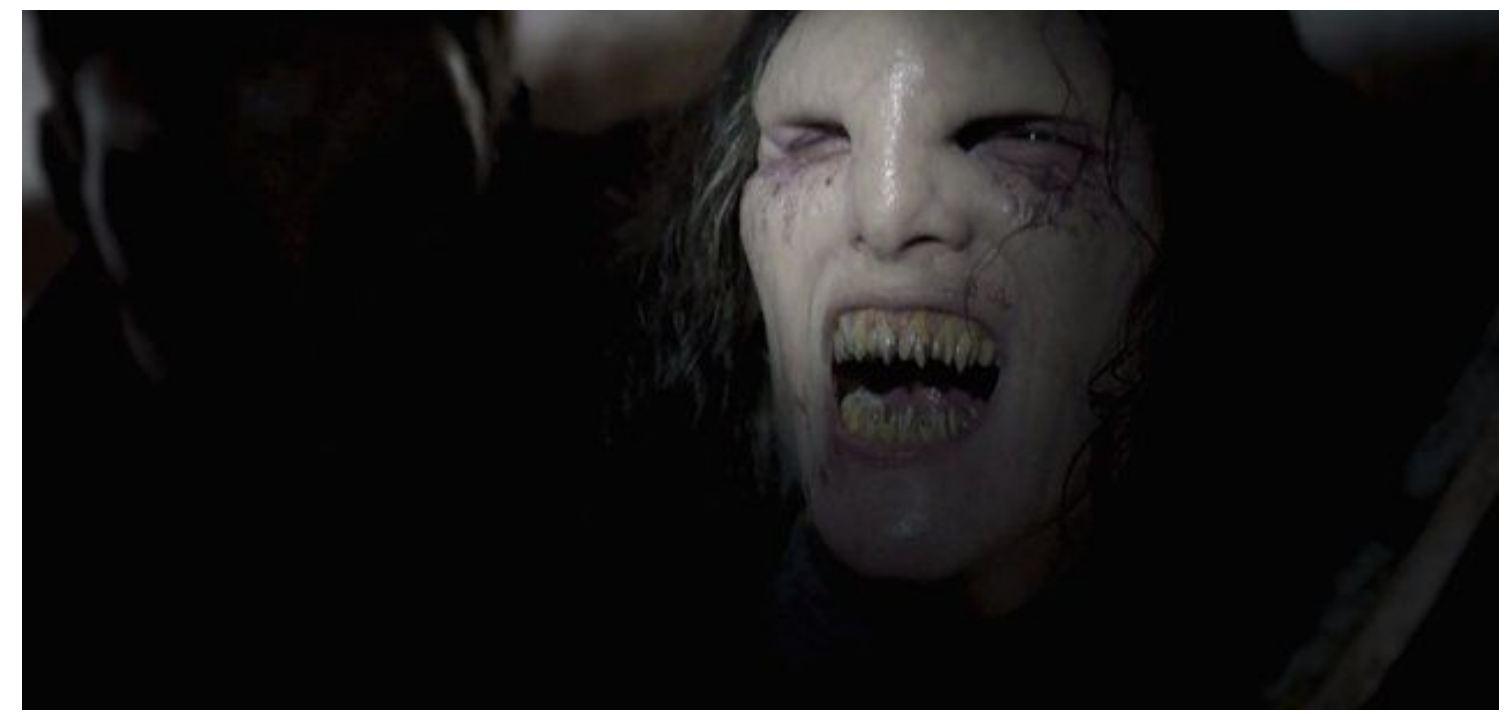

\section{CONCLUSIONES}

Las ficciones inmunitarias no solo tematizan, representan y convierten la lógica de la inmunidad en motor de sus tramas. Más que eso, producen en su público una experiencia de impacto y gran tensión que le prepara emocional e intelectualmente para un mundo colapsado y devastado por un contagio que puede ser vírico o bacteriológico, pero también social y cultural y en el que cobra una importancia esencial la necesidad de combatir hasta la muerte a un enemigo ficcional que encarna nítidamente la amenaza del contagio y la devastación. Participan del sobredimensionamiento de los peligros sociales que necesita la lógica inmunitaria para legitimarse, y sobrevisibilizan las violencias sociales potenciales para argumentar la necesidad de una violencia inmunitaria mayor, que pueda contenerlas y ponerles freno. Las ficciones inmunitarias forman parte, por tanto, de los dispositivos que el paradigma inmunitario articula para normalizar y naturalizar respuestas inmunitarias ante las amenazas reales o ilusorias que atraviesan el cuerpo social. Como es lógico, no todas lo hacen en el 
mismo grado ni con el mismo poder de persuasión e impacto en su público. Algunas llevan a cabo una representación compleja de las relaciones entre comunidad, amenaza e inmunidad y otras operan una gran simplificación moral de la que cualquier matiz se halla excluido. Pero en su tendencia general, al potenciar y consolidar los miedos y angustias sociales en torno a la amenaza del otro social, las ficciones inmunitarias construyen una apoyatura emocional para las nuevas formas de exclusión y segregación que genera el poder inmunitario y, en momentos extremos, para su deriva necropolítica. Pieza clave en la proliferación social de miedos derivativos, las ficciones inmunitarias no deben ser pensadas, sin más, como productos culturales para el entretenimiento o el placer estético, sino como elementos importantes en la naturalización de un reparto inmunitario de lo sensible o de una imaginación política de la inmunidad.

\section{BiBLIOGRAFÍA}

Agamben, G. (1999). Homo sacer. El poder soberano y la nuda vida. València: Pre-Textos.

Agamben, G. (2000). Lo que queda de Auschwitz. El archivo y el testigo Homo Sacer III. València: Pre-Textos.

Barel, Y. (1982). La marginalité sociale. París: PUF.

Bauman, Z. (2007). Miedo líquido. La sociedad contemporánea y sus temores. Buenos Aires: Paidós.

Boluk, S., y Lenz, W. (2010). Infection, media, and capitalism: from early modern plagues to postmodern zombies. The Journal for Early Modern Cultural Studies, 10, 126-147.

Brooks, M. (2015). Guerra mundial Z. Una historia oral de la guerra zombi. Córdoba: Berenice.

Camus, A. (1983). La peste. Barcelona: Edhasa.

Canavan, G. (2010). "We are the Walking Dead": Race, Time and Survival in Zombie Narrative. Extrapolations 51(3), 531-553.

Defoe, D. (2012/1772). Diario del año de la peste. Madrid: Impedimenta.

Domínguez Leiva, A. (2010). L'invasion néo-zombie: entre l'abjection, le grotesque et le pathos (2002-2009). Frontières 231, 19-25.

Domínguez Leiva, A. (2013). Invasion zombie. Neuilly-lès-Dijon: Le murmure. 
Esposito, R. (2005). Inmunnitas. Protección y negación de la vida. Buenos Aires: Amorrortu.

Esposito, R. (2012). Comunidad, inmunidad, biopolítica. Las Torres de Lucca. Revista Internacional de Filosofía Política, 1, 101-114.

Ferrer Ventosa, R. (2015). Infección controlada. Maneras de representar el estado de excepción en el cine de pandemias. Laocoonte: revista de estética y teoría de las artes, 2(2), 189-205.

Foucault, M. (1992). Genealogía del racismo. De la guerra de razas al racismo de Estado. Madrid: La Piqueta.

Gatti, G. (2015). ¿Tiene [la] palabra la víctima pura[?] El vacío social, el testimonio y la desesperación del investigador ante el sufrimiento sin forma ni lenguaje. Kamchatha. Revista de análisis cultural 6, 801815.

en: https://ojs.uv.es/index.php/kamchatka/article/view/7544/7730.

Girard, R. (1974). The Plague in Literature and Myth. Texas Studies in Literature and Language, 15(5), 833-850.

Hanson, H. (2006). Disaster Movies. En L. R. Williams y M. Hammond (Eds.), Contemporary American Cinema (pp. 128-133). New York: Open University Press.

Judt, T. (2009). Albert Camus: la alegoría política de la peste. Opera Mundi. Disponible en: http://www.operamundimagazine.com/2009/09/albert-camus-la-alegoria-politica-de-lapeste.html.

Klein, N. (2007). La doctrina del shock. El auge del capitalismo del desastre. Barcelona: Paidós.

Korstanje, M. (2012). Contagio y pandemia: crónicas de un desastre apocalíptico. Revista de antropología experimental, 12, 261-270.

Kristeva, J. (1988). Poderes de la perversión. Madrid: Siglo XXI.

Lauro, S. (2015). The Transatlantic Zombie: Slavery, Rebellion, and Living Death. New Brunswick: Rutgers University Press.

Loureiro, M. (2011). Apocalipsis Z. El principio del fin. Barcelona: Penguim Random House.

Martínez Fernández, Á. (2014). La escritura del shock. Crisis y poesía en España. Kamchatka. Revista de análisis cultural 4, 383-434. Disponible en: https://ojs.uv.es/index.php/kamchatka/article/view/4294/4409. 
Martínez, M. Á. (2015). Una lengua común: poéticas y políticas de la enfermedad. (Tesis doctoral inédita). Universitat de València, València. Disponible

en: http://mobiroderic.uv.es/handle/10550/50537.

Martínez, M. Á. (en prensa). Biopolíticas: la imaginación política sobre lo viviente. En J. Peris Blanes (Ed.), Cultura e imaginación política. Paris/México: Rilma2.

Mbembe, A. (2011). Necropolítica. Santa Cruz de Tenerife: Melusina.

Mbembe, A. (2016). Crítica de la razón negra. Ensayo sobre el racismo contemporáneo. Madrid: NED.

Molina Gil, R. (2015). De remakes, zombis y tradición(es). El caso del Lazarillo Z. Matar zombis nunca fue pan comido, $452^{\circ} \mathrm{F}(13), 148-170$. Disponible en: http://www.452f.com/pdf/numero13/13_452f_Molina_orgnl.pdf.

Moreman, C. M., y Rushton, C. J. (Eds.). (2011). Race, Oppression and the Zombie: Essays on Cross-Cultural Appropriations of the Caribbean Tradition. Jeffereson, North Carolina y Londres: McFarland.

Pérez Ochando, L. (2013a). George A. Romero. Cuando no quede sitio en el infierno. Madrid: Akal.

Pérez Ochando, L. (2013b). La ideología del miedo. El cine de terror estadounidense (2001-2011) (Tesis doctoral inédita). Universitat de València, València. Disponible en: http://roderic.uv.es/handle/10550/32686.

Pérez Ochando, L. (en prensa). Tinieblas ¿y amanecer? El cine apocalíptico y la ausencia de alternativas. En J. Peris Blanes (Ed.). Cultura e imaginación política. Mexico/Paris: Rilma2.

Peris Blanes, J. (en prensa). Comunidad, crisis social y paradigma inmunitario en las ficciones zombi contemporáneas. En G. Gatti y K. Mahlke (Eds.), Sangre y filiación en los relatos del dolor. Madrid/Frankfurt: Iberoamericana/Vervuert.

Pueyo, V. M. (2013). Después del fin de la historia: Estados de excepción y escenarios de emergencia en el cine de terror español contemporáneo (2002-2013). Arizona Journal of Hispanic Cultural Studies, 17(1), 29-46.

Rancière, J. (2009). El reparto de lo sensible. Estética y política. Santiago de Chile: LOM.

Sontag, S. (1996). Contra la interpretación. Madrid: Alfaguara. 
Sundaram, N (2012). Imagining Bio-Disaster, Reproducing Social Order. Epidemics in Contemporary Hollywood. Journal of Creative Communications, 7, 135-151.

Taibo, C. (2014). ¿Por qué el decrecimiento? Un ensayo en la antesala del colapso. Barcelona: Libros del Lince.

Watts, E. K. (2014). "The incessant moan": Reanimating zombie voices. Carroll C. Arnold Distinguished Lecture 2013. Washington, D. C.: National Communication Association.

Wynter, S. (1995). 1492: A new world view. Race, discourse, and the origin of the Americas: A new world view (1995), 5-57.

Zamora Llorente, A. (2015). De Madrid al Zielo. Madrid: Dolmen.

\section{FILMOGRAFÍA}

Boyle, D. (2002). 28 dias después. Londres: Fox Searchlight Pictures/ DNA Films/ UK Film Council (Film).

Brooker, Ch. (2011-2017). Black Mirror. Londres: Zeppotron (Serie TV).

DeMonaco, J. (2013). La purga. La noche de las bestias. Los Angeles: Universal Pictures/ Blumhouse Productions/ Platinum Dunes/ Why Not Productions (Film).

DeMonaco, J. (2014). La purga. Anarchy. Los Angeles: Blumhouse Productions/ Platinum Dunes/ Universal Pictures / Why Not Productions (Film).

DeMonaco, J. (2016). La purga. Election Day. Los Angeles: Blumhouse Productions/ Platinum Dunes/ Universal Pictures (Film).

Foster, M. (2013). Guerra mundial Z. Los Angeles: Paramount Pictures/ Skydance Productions/ GK Films/ Plan B Entertainment/ Apparatus Productions/ Hemisphere Media Capital/ Latina Pictures (Film).

Kirkman, R. (2003-2014). The Walking Dead. Image Comics (Comic).

Kirkman, R. y Darabont, F. (2010-2017). The Walking Dead. AMC (Serie TV).

Kirkman, R. y Erickson, E. (2015-2017). Fear the Walking Dead. AMC (Serie TV).

Lawrence, F. (2007). Soy leyenda. Los Angeles: Warner Bros. Pictures/ Village Roadshow (Film).

Pastor, A. y Pastor, D. (2013). Los últimos días. Barcelona: Antena 3 Films/ Morena Films/ Rebelión Terrestre/ Les Films du Lendemain (Film).

Petersen, W. (1995). Estallido. Los Angeles: Warner (Film). 
Romero, G. A. (1968). La noche de los muertos vivientes. Los Angeles: Image Ten/ Laurel Group/ Market Square Productions/ Off Color Films (Film).

Romero, G. A. (1978). El amanecer de los muertos. Los Angeles: Laurel Group (Film).

Romero, G. A. (1985). El día de los muertos. Los Angeles: Laurel Communications (Film).

Romero, G. A. (2005). La tierra de los muertos vivientes. Los Angeles: Universal Pictures (Film).

Romero, G. A. (2007). El diario de los muertos. Los Angeles: Artfire Films (Film).

Soderbergh, S. (2011). Contagio. Los Angeles: Warner (Film). 